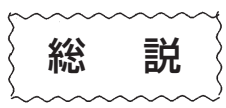

\title{
伝染性造血器壊死症
}

\author{
西澤豊彦 ${ }^{*} \cdot$ 吉水 守 $^{2}$
}

(2016年 8 月31日受付)

\section{Infectious Hematopoietic Necrosis}

\author{
Toyohiko Nishizawa ${ }^{1 *}$ and Mamoru Yoshimizu² \\ ${ }^{1}$ Department of Aqualife Medicine, Chonnam National University, Yeosu 59626, Republic of Korea \\ ${ }^{2}$ Faculty of Fisheries Sciences, Hokkaido University, Hakodate, Hokkaido 041-8611, Japan
}

(Received August 31, 2016)

\begin{abstract}
Infectious hematopoietic necrosis (IHN) is a disease of salmonid fishes, mainly Oncorhynchus spp., including rainbow trout $O$. mykiss and Atrantic salmon Salmo salar. IHN causes serious economic losses. It was initially known as endemic in sockeye salmon fry $O$. nerka and chinook salmon fry $O$. tschawytscha in West Coast of North America since the 1950s. However, it was spread to Japan, Korea and Taiwan in the 1970s. It was spread to Italy and France in the 1990s. Currently, IHN can be found in many parts of the world, including Russia and South America. Mortality due to IHN in fish with $\leq 0.5 \mathrm{~g}$ of body weight can reach $60 \%$ to $100 \%$. Mortality caused by IHN will reduces when fish grow bigger. However, the onset of $\mathrm{IHN}$ has also increased recently in fish with larger. Here, we describe the molecular epidemiology and virulence changes of IHN virus (IHNV) in Japan, and the detection and identification methods for IHNV. Furthermore, we will discuss the future prospects of IHNV researches.
\end{abstract}

伝染性造血器壊死症（infectious hematopoietic necrosis, IHN）は，IHNウイルス（IHN virus, IHNV）によるサ ケ科魚類の感染症で, ニジマス Oncorhynchus mykissを 含む Oncorhynchus 属抒よびタイセイヨウサケSalmo salarでの被害が甚大である。本病は, 1950年代頃から 米国西海岸でベニザケ O. nerka 抒よびマスノスケO. tschawytscha 稚魚の病気として知られていた。IHN は北 アメリカの風土病的存在であったが，1970年代に日本に 続き韓国や台湾で，また1990年代にはイタリアとフラン スで発生し, 現在ではロシアや南アメリカ大陸を含め世 界各地で発生が認められている（Bootland and Leong, 2011）。IHN は, 稚魚（魚体重 $\leq 0.5 \mathrm{~g}$ ）では累積死亡率 が60１00\%に達するが，成長に伴い死亡率は低下する。 マスノスケ, ベニザケおよびニジマスでよく発生するが, ギンザケO. kisutsh は抵抗性が高い（Kimura and Yoshimizu, 1991)。最近では冷水病との混合感染が多く,

\footnotetext{
${ }^{1}$ Chonnam National University

2 北海道大学水産学部

* Corresponding author

E-mail: jjnishi@jnu.ac.kr
}

大型魚の発症例が増し，時に親魚の死亡例も見られる。

\section{病原体}

IHNV は, Rhabdoviridae (ラブドウイルス科) Novirhabdovirus 属の基準ウイルスで, 同属には viral hemorrhagic septicemia virus (VHSV), hirame rhabdovirus（HIRRV）等が分類される（Dietzgen et al., 2012）。 IHNV 粒子は, 一般的に直径 70-80 nm, 長さ160-180 $\mathrm{nm}$ のエンベロープを有する砲弾型を呈し, 約11,000塩 基長の非分節マイナス鎖 RNA をゲノムとする。ウイル ス粒子は 5 つの構造タンパク質 [L (RNA polymerase), G (glycoprotein), N (nucleoprotein), P (phosphoprotein), M (matrix protein)] から構成され, ウイルスゲノ ムには 6 つの遺伝子（3'-N-P-M-G-Nv-L-5'） が存在する (Dietzgen et al., 2012)。G と L 遺伝子の間に位置する Nv 遺伝子は, non-virion protein をコードし，本属が novirabhdovirus と命名された由縁である。

Gタンパク質は, IHNV 粒子表面のエンベロープに組 み込まれ, 細胞のレセプターと結合するリガンドとして 機能する。また, 抗 Gタンパク質抗体がウイルス中和能 
を有することから, 本タンパク質は重要な感染防御抗原 の一つである（Bootland and Leong, 2011）。IHNV の血 清学的関係は，ポリクローナル抗体（PAbs）を用いた試 験ではほぼ均一であるが，モノクローナル抗体 (MAbs) を用いた試験では若干の差異が認められる（Bootland and Leong, 2011)。なお中和試験および蛍光抗体法等で, IHNV は VHSV や HIRRV と交差しない。

\section{分子 疫 学}

日本でのIHN は，1971年に北海道立水産ふ化場森支場 で前年度にアラスカ州から輸入されたベニザケ発眼卵と 共に卵管理されていたヒメマス幼魚で初めて発生し，翌 年には北海道さけ・ますふ化場虹別事業場でアラスカ州 産べニザケ発眼卵由来仔魚拉よび虹別ならびに千歳支場 産ヒメマス仔魚で発生した（Yoshimizu, 1996）。従って, 日本のIHNV は，ベニザケ污染卵と共に米国より持ち込 まれたと考えられている。その後1974年に長野および静 岡県下のニジマスにも発生し, 以来日本各地のニジマス や在来マスにも感染が拡大した。2000年代後半になり, 長年保存されていた日本株のゲノム解析と病毒性試験が 実施され，興味深い事実が明らかになった。まず，米国

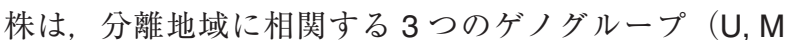
and L) に分類される (Bootland and Leong, 2011)。Uは
西海岸北部アラスカ州からワシントン州の株, M はコロ ンビア川流域からアイダホ州の中部地域株，そして Lは オレゴン州南部からカリフォルニア州にかけての南部地 域株である。1970年代の日本株は何れもUに分類され, 米国株を含めた多様性は1.8\%以下であった。これに対し， 1980年代以降の日本株は新しいゲノグループ (JRt) を形 成した（Fig. 1; Nishizawa et al., 2006)。即ち，Yoshimiuzu et al.（1996）の疫学調査が示唆した如く，1970年代に米 国U株が日本に持ち込まれ，その後独自の進化を遂げた ことが分子疫学的に裏付けられた。なお，ヨーロッパ株 は，米国 M 株を祖先型とし，ヨーロッパで独自に進化し た（Fig. 1)。これは，日本では過去にべニザケ卵を米国 西海岸北部地域から輸入していたが，ヨーロッパではニ ジマス卵を米国西海岸中部地域から輸入していた事とも 合致する。

日本のニジマス養殖場で独自に進化したIHNV の多様 性は，米国株に比べ有意に大きいことから（Fig.1）, IHNV の分子進化速度が日本の養殖環境下で加速してい ることが示された（Nishizawa et al., 2006）。さらに, 2000年代の日本株はニジマスに対し強い病毒性を示した が，1970年代株の病毒性は極めて低かった（Mochizuki et al., 2009)。但し，1970年代に行った実験では， 1970 年代株もニジマスに強い病毒性を示した。従って, ニジ

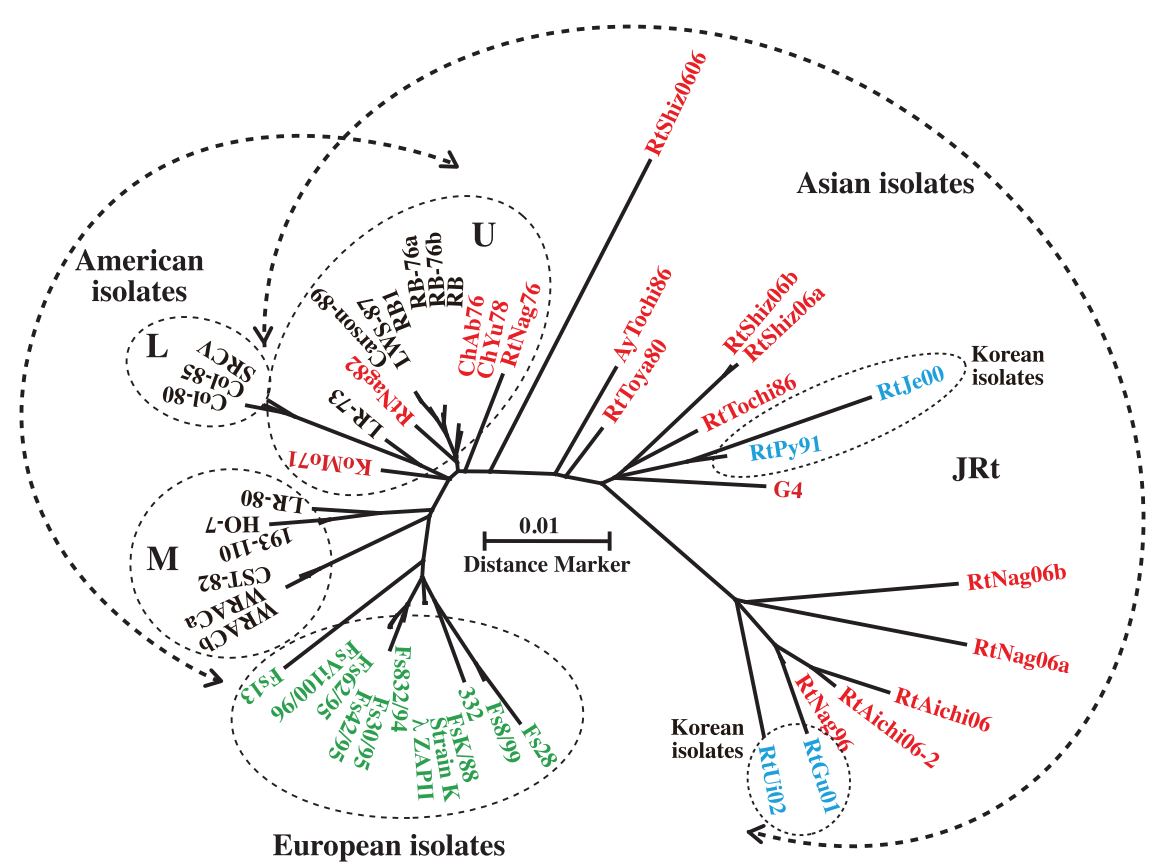

Fig. 1. Molecular phylogeny among 49 isolates of infectious hematopoietic necrosis virus (IHNV) based on nucleotide sequences of glycoprotein gene's open reading frame. The distance marker refers to the expected number of substitutions per site. Black, green, red and light blue letters indicate North American, European, Japanese and Korean isolates, respectively. The first two letters of each isolate name indicate the host fish; i.e. Ch, Ko, Rt and Ay denote chum salmon, kokanee salmon, rainbow trout and ayu Plecoglossus altivelis, respectively. The following letters indicate the area of isolation. Ab, Yu and Mo denote Abashiri, Yurappu, and Mori of Hokkaido. Nag, Toya and Tochi denote Nagano, Toyama and Tochigi Prefectures of Honshu. The final two letters indicate years of virus isolations. The present phylogeny was update from that of Mochizuki et al. (2009). 

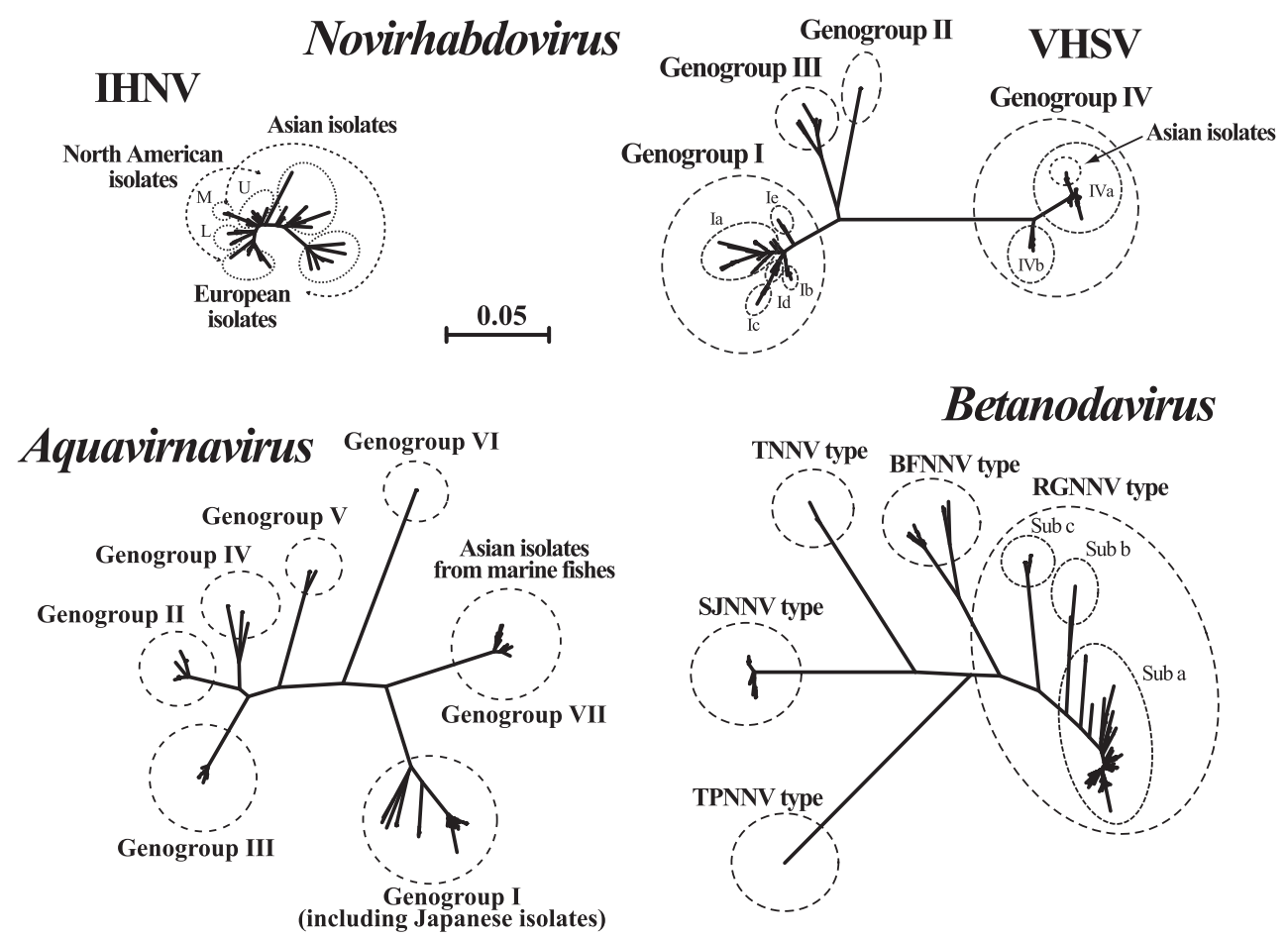

Fig. 2. Comparison of nucleotide diversity among infectious hematopoietic necrosis viruses (IHNV) and viral hemorrhagic septicemia viruses (VHSV) in Novirhabdovirus, infectious pancreatic necrosis viruses and others isolates in Aquavirunavirus, and nervous necrosis viruses (NNV) in Betanodavirus. The distance marker refers to the expected number of substitutions per site.

マスのIHNV 感受性は, 生残魚の自然選抜により徐々に 低下してきたが，それを上回る速さでIHNVの病毒性が 上昇していると考えられる (Mochizuki et al., 2009)。

IHNVの遺伝的多様性は, VHSV, aquabirnavirus (ABV) あるいは nervous necrosis virus（NNV）に比べ 遙かに小さい（Fig. 2)。これは, 1970年以降に米国西海 岸の風土病であったIHNが，IHNV 污染卵の移動により 世界各地に拡散したことを裏付けている。興味梁いこと に, IHNV を含む各RNAウイルスに㧍ける系統樹末端で の分子進化速度に大きな差異は無い。即ち, VHSV, ABV およびNNV は病原体として発見される遙か以前に, 各 地で独自にゆっくりと進化し, ある程度の多様性が既に 確立されていたと考えられる。また，ウイルスが新たな 宿主と出会い病原体として発見された後, その進化速度 は急激に加速されたと考えられる。IHNVもニジマスと いう新たな宿主で，現在も急速な進化を続けている様で ある（Fig. 1)。日本のニジマス養殖場では IHN 生残魚を 人為的に作出し, 養殖に供する地域があり, これらの行 為はIHNV 強毒株の作出を助長している可能性がある。

\section{症状および組織病理}

IHN 罹病魚は, 活動が鈍くなり，浮上し流れに向かっ て力無く泳ぎ，時に激しく泳ぐが，やがて死亡する。罹 病魚は, 腹水貯留, 眼球突出, 貧血を呈し, 特に鰓の裉 色が著しい。胸鰭基部や肛門付近の躯幹筋に V 字状の出
血が認められることもある（Fig. 3A）。大型魚では, 腹 腔壁, 脾臟と幽門垂周辺の脂肪組織, 腹膜, 脳や心臓を 囲む膜などにしばしば出血点が見られる。組織病理では, 腎臟造血組織の激しい壊死および脾臟造血組織の壊死が 特徵的である。症状が進むと, 肝臟にも巣状壊死が, ま た胃腸固有層の顆粒細胞に壊死が見られる。また, 脾臓 の腺房およびランゲルハンス島の細胞の部分的な退行変 性・壞死も例外なく見られる (Wolf, 1988)。

\section{検 出・同 定}

IHNV の検出は, 分離培養が基本である。IHNV は, RTG-2, CHSE-214, FHM 細胞や他のサケ科魚由来株化 細胞でも良く増殖する。IHNV の増殖温度域は $13^{\circ} \mathrm{C} \sim$ $20^{\circ} \mathrm{C}$ で, 至適温度は $15^{\circ} \mathrm{C} \sim 18^{\circ} \mathrm{C}$ である。IHNV に感染 した株化細胞は球形化し房状に集合した後, 培養器底か ら剥離する (Fig. 3B)。IHNV 感染による細胞変性効果 (cytopathic effect, CPE) は VHSV や HIRRV 感染と類似 するため, 培養後に蛍光抗体法 (Fig. 3D) P RT-PCR 等 による同定が不可欠である (OIE, 2016)。蛍光抗体法, ELISA および RT-PCR 等で, 病魚からのIHNV 直接検出 も可能であるが，死因特定を目的とする場合には検体中 に IHNV が critical level（臨界值）以上存在することを確 認する必要がある。経験值ではあるが, IHNV の critical level は感染価で $10^{6} \mathrm{TCID}_{50} / \mathrm{g}$-tissue, ゲノム量で $10^{8}$ genome/g-tissue 程度である。 

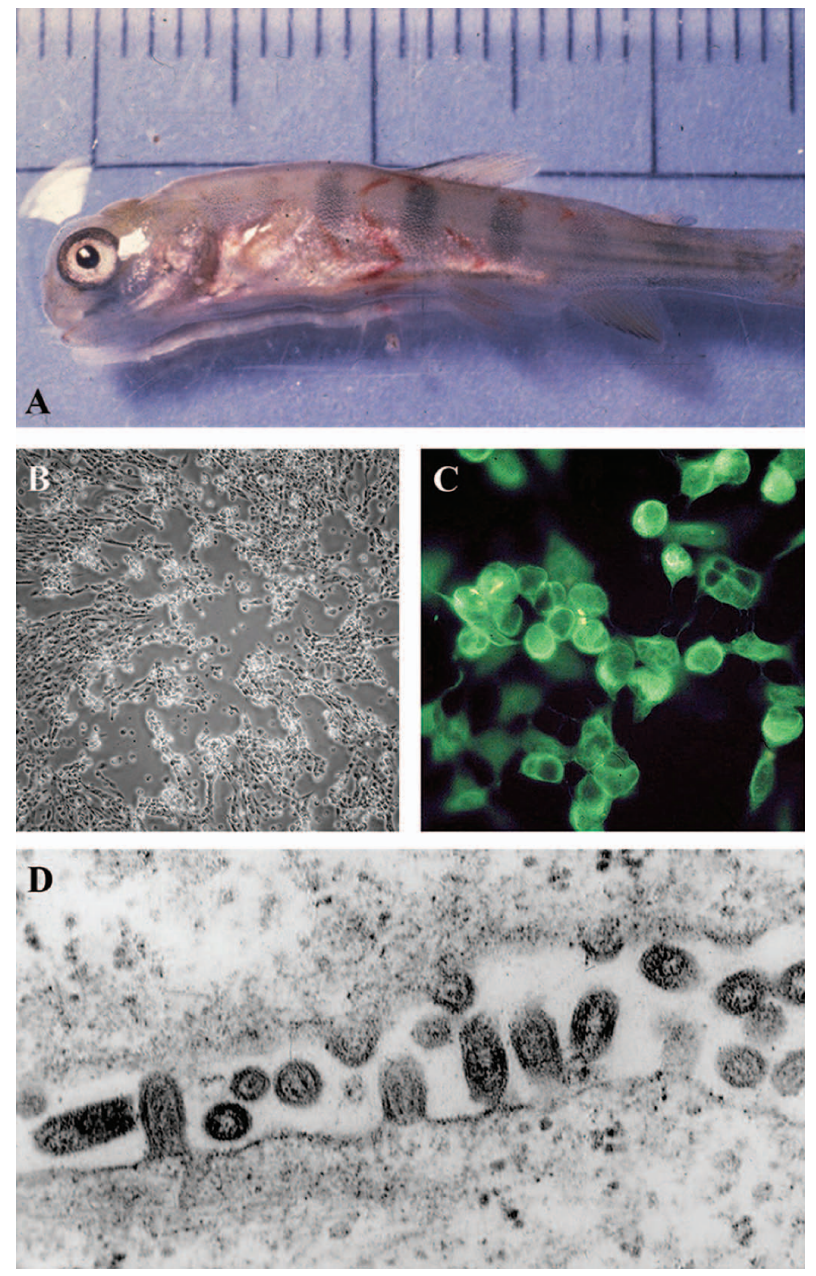

Fig. 3. Photos of infectious hematopoietic necrosis (IHN)affected fish and detection methods of IHN virus (IHNV). A: Masou salmon affected with IHN. B: Cytopathic effect (CPE) observed in RTG-2 cells at 4 days after inoculation of IHNV. C: Detection of RTG-2 cells infected with IHNV by immunofluorescence antibody test (IFAT) using rabbit antiserum against IHNV. D: Budding IHNV particles from RTG-2 cells observed with a transmission electron microscope.

最近，IPNV 等のウイルスと混合感染している検体が 多数見られる。IPNV と混合感染した検体からのIHNVの 分離培養では，予め検体中のIPNV を抗 IPNV 血清で完 全に中和する必要があり，操作は煩雑である。近年， IPNV に持続感染した EPC 細胞が樹立された。本細胞は, IHNV あるいはVHSV に対する感受性を維持しながら， IPNV には感受性を示さない (Kim et al., 2012)。従って, 本持続感染細胞を用いれば, IPNV 混合感染検体からで もIHNVの分離・培養が容易である。

\section{防 除 対 策}

魚類では母子免疫は成立せず，また仔稚魚期（サケ科 魚類では, $0.3 \mathrm{~g}$ 以下）に液性免疫の応答が認められな い。従って，ワクチンによる予防対策が有効になるまで
の期間は，衛生管理，親魚選別，および卵消毒を柱とし た防除対策が重要である。

1）衛生管理：IHNV は，消毒剂に対し比較的感受性が高 い。手指の消毒には塩化ベンザルコニウム液（200ppm） あるいはクレゾール石ケン液（100 ppm）が，器具類お よび水槽等の消毒等には次亜塩素酸ナトリウム溶液（有 効塩素濃度 50 ppm）が各々有効である。また，飼育水 の殺菌には，低圧紫外線の照射 $\left(10^{4} \mu \mathrm{W} \cdot \mathrm{sec} / \mathrm{cm}^{2}\right)$ が 有効である（吉水・笠井, 2002）。

2）親魚選別：IHNV 感染耐過魚では, 成熟期の生殖産物 (卵巣腔液抒よび精液)にIHNV が出現し，垂直感染（経 卵感染）の污染源となる（Yoshimizu et al., 1993）。开 ケ・マス類では受精後, 発眼に至るまで約 1 ケ月を要す るため, 採卵時に卵巣腔液のIHNV 検査を実施できる。

3）受精卵の消毒 : 産卵親魚の体腔液に排出されたIHNV は精子あるいは卵を污染し，仔稚魚におけるIHN 発症の 原因になることから，IHNV の垂直感染は避けられない と考えられてきた。しかし，精子と共に卵内に侵入した IHNV は胚に感染し，最終的に肧は死亡する。また，卵 内のIHNV は卵内容物により不活化される。卵表面に吸 着したIHNV も経卵垂直感染の原因になるが，発眼期に 卵をポピドンヨード処理 (50 ppm，15分）することで卵 表面のIHNV は不活化される。従って, 死卵の除去およ び発眼卵の消毒により，IHNV の経卵垂直感染は阻止可 能である (Yoshimizu, 2003)。

\section{予防}

これまで，不活化および弱毒 IHNV ワクチン，遺伝子 組換えGタンパク質および同タンパク遺伝子を用いた DNA ワクチン等が開発されてきたが（Bootland and Leong, 2011), 多くは市販には至っていない。近年 DNA ワクチンがカナダで市販され話題になった。また，Poly （I:C）（合成 2 本鎖 RNA）投与後に病毒 IHNV を接種す ることで，ニジマスに強力な防御免疫を誘導する新たな 免疫法が考案された（Kim et al., 2009）。本法は, VHSV やNNVでも有効である。一方，飼育温度管理された魚 （ウイルス増殖温度域内で且つ発症温度域外）に病毒ウイ ルスを接種することでも, 強力な感染防御が誘導される ことが VHSV，NNV および red seabream iridovirus (RSIV) で示された（Nishizawa et al., 2011, 2012; Oh et al., 2014)。本免疫法の原理は，温度管理によりウイルス の増殖速度を制御することで， ウイルスの病毒性を間接 的に抑制することにある。IHNV は20 ${ }^{\circ} \mathrm{C}$ 増殖可能である が，同温度でIHN は発症しないため，本免疫法の応用は 将来的に十分期待できる。

\section{最近の研究動向・残された課題}

1960年代に魚類株化細胞が樹立されて以降，IHNVの 
研究は飛躍的に進歩し, 診断・検出法および解析法はほ ぼ成熟期に至った。防除法も Yoshimizu（2003）の方法 が世界標準となり完結した。IHN対策で残された課題は, ワクチンを含めた予防法と治療法の確立である。これま でのIHNV ワクチンは, relative percent survival (RPS) 值60\%以上で，実験的に十分に有効である。しかし，本 RPS 值は養殖業者にとっては微妙である。IHNの様に非 免疫魚の死亡率が $100 \%$ 近くに達する場合, RPS 值 $60 \%$ のワクチンを投与した魚でも計算上 $40 \%$ 相当が死亡する ため, 養殖業者がワクチンの効果に疑問を抱くのも当然 である。養殖業者が求めるワクチンとは，おそらくRPS 值が $80 \%$ 以上であろう。これに対し， ウイルス感染耐過 魚の防御能は極めて高い（RPS 值 $95 \%$ 以上）。即ち，人 為的に感染耐過魚を作り出す, いわゆる生ワクチンであ れば，養殖業者も十分満足である。最近まで，生ワクチ ンの開発・研究は殆ど行われなかった。これは, 免疫魚 が持続感染することで, 病原体を排出し続け, 養殖環境 の污染に慗がることが懸念されるためである。IHNの防 除対策はすでに確立され，北海道および東北地方では IHN の発生はない。デンマークでは, ゾーニングと徹底 した衛生管理でVHSの駆除に成功した。残念ながら，本 州中部ではニジマス等をIHNV 污染環境下で養殖せざる を得ない地域があり, あえて感染耐過魚を作出して養殖 に供する業者も見受けられる。しかし，これらはIHNV の変異を助長し, 強毒株の作出に繋っている。研究過程 ではあるが，十分に免疫された感染耐過魚では，免疫に 用いたウイルスが最終的に排除される様である。とすれ ば, 安全で効率的な感染耐過魚の作出方法の開発は産業 的にも重要である。そのためには, ウイルスの病毒性機 構ならびに持続感染機構の研究を進め, ウイルス感染耐 過メカニズムの解明が不可欠である。さらに, これらの 研究は, ウイルス感染魚の治療法の確立へと発展すると 考えている。

\section{文献}

Bootland, L. M. and J. C. Leong (2011): Infectious hematopoietic necrosis virus. In "Fish Diseases and Disorders, Vol. 3: Viral, Bacterial and Fungal infections, 2nd Edition" (ed. by P. T. K. Woo and D. W. Bruno). CAB international, Oxfordshire, UK, pp. 66-109.

Dietzgen, R. G., C. H. Calisher, G. Kurath, I. V. Kuzmin, L. L. Rodriguez, D. M. Stone, R. B. Tesh, N. Tordo, P. J. Walker, T. Wetzel and A. E. Whitfield (2012): Family Rhabdoviridae. In "Virus Taxonomy: Ninth report of the international committee on taxonomy of viruses" (ed. by A. M. Q. King, M. J. Adams, E. B. Carstens and E. J. Lefkowitz). Elsevier Academic Press, San Diego, CA, pp. 686-713.

Kim, H. J., N. Ohseko, T. Nishizawa and M. Yoshimizu (2009):
Protection of rainbow trout from infectious hematopoietic necrosis (IHN) by injection of infectious pancreatic necrosis virus (IPNV) or Poly (I:C). Dis. Aquat. Org., 83, 105-113.

Kim, H. J., J. K. Cho, H. K. Hwang, M. J. Oh and T. Nishizawa (2012) : Establishment and characterization of the epithelioma papulosum cyprini (EPC) cell line persistently infected with infectious pancreatic necrosis virus (IPNV), an aquabirnavirus. J. Microbiol., 50, 821-826.

Kimura, T. and M. Yoshimizu (1991): Viral diseases of fish in Japan. Ann. Rev. Fish Dis., 1, 67-82.

Mochizuki, M., H. J. Kim, H. Kasai, T. Nishizawa and M. Yoshimizu (2009): Virulence change of infectious hematopoietic necrosis virus against rainbow trout Oncorhynchus mykiss with viral molecular evolution. Fish Pathol., 44, 159-165.

Nishizawa, T., S. Kinoshita, S. Higashi, W. S. Kim and M. Yoshimizu (2006): Nucleotide diversity of Japanese isolates of infectious hematopoietic necrosis virus (IHNV) based on the glycoprotein gene. Dis. Aquat. Org., 71, 267-272.

Nishizawa, T., I. Takami, M. Yang and M. J. Oh (2011): Live vaccine of viral hemorrhagic septicemia virus (VHSV) for Japanese flounder at fish rearing temperature of $21^{\circ} \mathrm{C}$ instead of Poly (I:C) administration. Vaccine, 29, 83978404.

Nishizawa, T., H. J. Gye, I. Takamia and M. J. Oh (2012): Potentiality of a live vaccine with nervous necrosis virus (NNV) for sevenband grouper Epinephelus septemfasciatus at a low rearing temperature. Vaccine, 30, 1056-1063.

Oh, S.-Y., M. J. Oh and T. Nishizawa (2014): Potentiality of a live vaccine with red seabream iridovirus (RSIV) for rock bream Oplegnathus fasciatus by controlling fish rearing temperature. Vaccine, 32, 363-368.

O.I.E. (world organization for animal health) (2016): Infectious hematopoietic necrosis. Chapter 2.3.4, Manual of diagnostic tests for aquatic animals. http://www.oie.int/internationalstandard-setting/aquatic-manual/access-online/.

Yoshimizu, M. (1996): Disease problems of salmonid fish in Japan caused by international trade. Rev. Sci. Tech. Off. Int. Epiz., 15, 533-549.

Yoshimizu, M. (2003): Control strategy for viral diseases of salmonids and flounder. In "Biosecurity in aquaculture production systems: Exclusion of pathogens and other undesirables" (ed. by C. S. Lee and P. J. O'Bryen). World Aquaculture Society, AIP workshop, Baton Rouge, Louisiana, USA, pp. 35-41.

吉水 守・笠井久会 (2002) : 種苗生産施設における用水およ び排水の殺菌. 工業用水, 523, 13-26.

Yoshimizu, M., T. Nomura, Y. Ezura and T. Kimura (1993): Surveillance and control of infectious hematopoietic necrosis virus (IHNV) and Oncorhynchus masou virus (OMV) of wild salmonid fish returning to the northern part of Japan 1976-1991. Fish. Res., 17, 163-173.

Wolf, K. (1988): Infectious hematopoietic necrosis. In "Fish viruses and fish viral diseases" (ed. by K. Wolf). Cornell University Press, Ithaca, N.Y., pp. 83-114. 